\title{
Effect Of Using Water Extract Of Nettle Leaf (Urtica Dioica) On Some Microbial Characteristics Of Broiler Chickens
}

\author{
Ahmed Ali Kadhem Al-Salhi \\ College of agriculture and marshes- thi qar university-iraq \\ Department of Animal Production \\ Email- ahmed.a.k.alsalhi@gmail.com
}

\begin{abstract}
This study was conducted in the poultry field belonging to the Department of Animal Production at the College of Agriculture at Al-Muthanna University for the period from 10/25/2017 to 12/5/2017 to know the effect of using a82queous extract of nettle leaves on some microbial characteristics of broilers. In this experiment, 240 chicks were used. From broiler strain (Ross308), one day old, with an average weight of (43) gm, it was randomly distributed into four parameters, at 60 chicks per treatment, with three replications for each treatment, 20 chicks/repetition, and was raised in fourstory batteries, each floor contains a cage With an area of $1.5 * 1$ square meter. The experimental treatments included: the first treatment, $\mathrm{T} 1$, the control treatment, without any addition. As for the other treatments $(T 2, T 3$, and $4 \mathrm{~T}$ ), the aqueous extract of nettle leaves was added to it in three concentrations $(10,15,20) \mathrm{ml} /$ liter of drinking water, respectively. The results of the study showed that there was a significant decrease $(P \leq 0.05)$ in the logarithmic numbers of both total aerobic and coliform bacteria, with a significant increase $(P \leq 0.05)$ in the logarithmic numbers of lactobacilli in the duodenum, jejunum, and ileum in favor of the aqueous extract of discoid leaves compared to the control treatment.
\end{abstract}

keywords: Nettle, Urtica Dioica, , water extract ,Bacterial Count, Chicken Intestine, Broilers.

\section{Introduction}

Nettle is a herbaceous plant that spreads in different places Of Iraq and some Arab and foreign countries. Nettle is one of the genera of the Urticaceae family, which includes a group of plants with fine thorns, and the genus Nettle consists of several species, there are three types of them in Iraq: Urtica dioica And Urtica Urens, and Urtica Pilulifera, which differ from each other in leaf size and plant height (AL-Rawi and Chakravarty, 1988) The nettle plant is one of the medicinal plants distinguished by its therapeutic efficacy, so it is among the groups in small areas of Africa (Kavalali, 2004, Bhat \& Moskovitz, 2009; Roberts; 2012). Some studies point to the importance of using nettle as additives in animal diets, especially poultry (Hughes et al., 1980 (The use of plant extracts for domestic birds can 
grow plant growth and reduce research workers from nutrients), 2002) where Safanah et al. (2012) noted the extract The aqueous of the pineapple leaves, is beautiful in the synthesis of E. coli bacteria by its action of the compounds it contains, flavonoids, phenols, and it can also be used as a food preservative, as it contains the properties of the bacterial synthesis. Farhan (2012) confirmed this that the aqueous extract with a concentration of $0.5 \mathrm{~g} / \mathrm{I}$ had an effective effect in inhibiting the growth of E. coli when studying the effect of aqueous extracts on different types of bacteria. Abouhosseini et al. (2016) also noted an improvement in increasing the numbers of E. coli. Lactobacillus, with reduced numbers of Escherichia Coli bacteria, when studied, in which nettle root extract was used with $5.0 \mathrm{~g} /$ $\mathrm{kg}$ of nettle root extract to evaluate its effects on the microbial traits of Ros 308 males for 42 days on 120 birds. In addition to the previous studies and the lack of local studies on the aqueous extract of nettles leaves and its effect on the microbial characteristics of broilers, as well as to educate breeders about the importance of using medicinal plant extract as a safe alternative to the use of chemical drugs that hurt the health of the consumer, the current study came intending to know the effect of adding the extract. Watery nettle leaf to drinking water in some microbial traits of broiler strain (Ross 308).

\section{Materials And Methods}

The experimental treatments included:

Experimental treatments included: First treatment (T1) Control treatment without any addition of plant extract, the other treatments $(\mathrm{T} 2, \mathrm{~T} 3$, and $\mathrm{T} 4)$ were added to the water extract of nettle leaves with three concentrations $(10,15,20) \mathrm{ml} / \mathrm{l}$ in the drinking water, respectively. Birds were fed on two types of diets, a starter for $1-21$ days, containing $23.04 \%$ protein and $2951 \mathrm{kcal}$ per $\mathrm{kg}$, and a finisher for $22-42$ days, containing $20.55 \%$ protein and $3098 \mathrm{kcal}$ per $\mathrm{kg}$ of energy. The pelleted feed was produced by Al-Hafiz company, Karbala Private, Iraq.

Table 1. Ingredients and chemical composition of the starter and finisher diets

\begin{tabular}{lcc}
\hline Ingredients $\%$ & Starter (1-21) days & Finisher (22-42) days \\
\hline Corn & 38 & 39.3 \\
\hline Wheat & 21 & 26 \\
\hline Soybean meal 44\% & 38.4 & 31 \\
\hline Mixture Vitamins And metal & 1 & 1 \\
\hline Plant oil & 0.5 & 0.6 \\
\hline Limestone & 0.8 & 0.3 \\
\hline Day Calcium Phosphite & 0.3 & 0.6 \\
\hline
\end{tabular}


ISSN Onlin:2708-9347, ISSN Print: 2708-9339 Volume 9, Issue 1 (2020) PP 13-23

https://jam.utq.edu.iq/index.php/mai Doi: https://doi.org/10.54174/UTJagr.Vo9.N1/02

\begin{tabular}{lcc}
\hline Total & 100 & 100 \\
\hline & Installation & \\
\hline Crude protein \% & 23.04 & 20.55 \\
\hline ME kcal/kg & 2951 & 3098 \\
\hline Calcium \% & 0.93 & 0.85 \\
\hline Phosphorous Available \% & 0.48 & 0.45 \\
\hline Methionine \% & 0.55 & 0.5 \\
\hline Lysine\% & 1.35 & 1.25 \\
\hline Methionine + Cysteine \% & 0.91 & 0.85 \\
\hline Folic acid \% & 1.2 & 1.1 \\
\hline Calculated analysis according to NRC (1994). & & \\
\hline
\end{tabular}

\section{Preparation of aqueous extract and method of use}

After obtaining the dried nettle leaves from the local market, they were thoroughly cleaned of impurities, and then milled by an electric grinder into a fine powder, then prepared according to the modified method of Hernandez et al. (1994); By mixing an amount of dry powder with a quantity of distilled water at a ratio of $1 \mathrm{~g}: 20 \mathrm{ml}$ of distilled water, and mixing both the solvent (distilled water) and the solute (nettle leaf powder) using an electric mixer. To obtain a homogeneous solution, then transfer this solution to the water bath at a temperature of $55^{\circ} \mathrm{C}$ for one hour, To ensure complete solubility and homogeneity, and at the end of the extraction process, the solution was left for 24 hours at room temperature, after which it was filtered with gauze. To capture the precipitate particles and take the leachate that was produced from the extraction process to be ready for use in the experiment.

Table 2. Results of the qualitative and quantitative chemical detection of the nettle leaf infusion.

\begin{tabular}{cc|}
\hline Active compounds & $\mathrm{Ml} / \mu \mathrm{g}$ \\
\hline flavonoids & $\underline{0.2993}$ \\
\hline phenols & $\underline{3.826}$ \\
\hline Saponins & $\underline{0.816}$ \\
\hline Tannins & $\underline{0.773}$ \\
\hline Steroids & $\underline{0.5415}$ \\
\hline Terpenes & $\underline{0.7891}$ \\
\hline
\end{tabular}




$\begin{array}{ll}\text { Materials } & \text { Weight (g) }\end{array}$

The analysis was done in the modern science laboratories in Diwaniyah / Hay Al-Jazayer.

\section{Preparation of peptone and culture media}

Prepare the peptone water solution

Prepare by dissolving $1 \mathrm{~g}$ of peptone in $1000 \mathrm{ml}$ of distilled water, then distribute to decimal dilution tubes and sterilize the Autoclave at $121^{\circ} \mathrm{C}$ and pressure 1.5 atmospheres for 15 minutes (Harrigan and McCance, 1976).

\section{Agricultural media}

The following culture media were used that were sterilized in the Autoclave at a temperature of 0121 $\mathrm{m}$ and a pressure of 1.5 atmospheres for 15 minutes.

\section{Preparation of Nutrient Agar}

Prepare according to the instructions of the Indian prepared company (Himedia), by dissolving $28 \mathrm{~g}$ of the nutrients in $1000 \mathrm{ml}$ of distilled water, then heat the mixture to a boil for one minute and use it to estimate the total number of bacteria.

\section{Preparation of MacConKey Agar}

Prepare according to the instructions of Oxiod, an English prepared company, by dissolving 51 grams of MacConKey solid in $1000 \mathrm{ml}$ of distilled water, then heat the mixture to a boil for one minute and use it to estimate the number of coliform bacteria.

\section{Preparation of MRS Agar}

It was used for the total count of Lactobacillus acidophilus cells prepared as reported by Harrigan and McCance (1976) by dissolving the following components in one liter of distilled water. Shown in Table (3).

Table 3. the most important components of MRS Agar. 


\section{Microbial examinations \\ The microbial \\ examinations \\ conducted in the postgraduate laboratory at the College of Agriculture at Al-Muthanna University, as $1 \mathrm{~g}$ of the contents of the small intestine}

\begin{tabular}{lc}
\hline Peptone & 10 \\
\hline Meat Extract & 10 \\
\hline Sodium acetate & 5 \\
\hline Yeast Extract & 5 \\
\hline Triammonium Citrate & 2 \\
\hline K3HPO4 & 2 \\
\hline Tween 80 & 0.2 \\
\hline MgSo4 & 0.2 \\
\hline MnSo4.4H2o & 0.05 \\
\hline Glucose & 20 \\
\hline Agar & 15 \\
\hline
\end{tabular}
prepared peptone water solution was added to be the first dilution of $10-1$, and save the solution In the refrigerator at a temperature of $4^{\circ} \mathrm{C}$ until the microbial count is performed.

\section{Estimate the total number of bacteria}

Four glass tubes containing $9 \mathrm{ml}$ of Pepton water solution were prepared, and $1 \mathrm{ml}$ of the initial dilution solution 10-1 was taken to the first tube to be the dilution 10-2 and $1 \mathrm{ml}$ of it was taken to the second tube, and so on to the fourth tube so that the ratio of dilution was 10-5, then transferred $1 \mathrm{ml}$ of Each decimal dilution by sterile pipette into two empty sterile Petri dishes (Duplicate), and directly to each dish, $15 \mathrm{ml}$ of sterile Nutrient Agar are added to estimate the total number of aerobic bacteria according to the Pour Plate Count method mentioned in (1978) APHA.

\section{Estimate the total number of coliform bacteria}

Three glass tubes containing $9 \mathrm{ml}$ of Pepton water solution were prepared, and $1 \mathrm{ml}$ of the initial dilution solution 10-1 was taken to the first tube to be the 10-2 dilution, and $1 \mathrm{ml}$ of it was taken to the second tube, and so on to the third tube so that the dilution ratio was 10-4, and it was also used. The Pour Plate Count method mentioned in (1978) APHA to estimate the total number of total coliform bacteria, by transferring $1 \mathrm{ml}$ of each decimal diluent using a sterile pipette into two empty sterile Petri dishes (Duplicate), and directly add $15 \mathrm{ml}$ of sterile culture medium to each plate. The pre-prepared MacConKey Agar feeder, then the colony rate is taken and then multiplied by the dilution reciprocal to obtain the number of germs colonies / g of the gut sample (colony /g).

\section{Estimate the total number of Lactobacilli bacteria}


I prepared six glass tubes containing $9 \mathrm{ml}$ of Pepton's water solution, and $1 \mathrm{ml}$ of the initial dilution solution 10-1 was taken to the first tube to make the dilution $10-2$, and $1 \mathrm{ml}$ of it was taken to the second tube and so on to the sixth tube so that the dilution ratio was $10-7$, and I used the Pour method The Plate Count reported by Speak (1984) using solid MRS to estimate the total number of L. acidophilus bacteria.

\section{XIII. statistical analysis}

A complete random design (CRD) was used to study the effect of different parameters on microbial traits. The significant differences between the averages were compared with the Duncan (1955) polynomial test under the 0.05 significance level, and the program SPSS (2018) was used in the statistical analysis.

\section{Results and discussion}

It is evident from the tables below $(4,5,6)$ that the aqueous extract treatments contributed to obtaining good results through increasing the numbers of Lactobacilli bacteria and reducing the numbers of total aerobic and coliform bacteria in the parts of the digestive system (duodenum, jejunum, and ileum) according to the level of addition compared With a control treatment.

The reason may be attributed to the efficacy of the aqueous extract of nettle leaves due to the potent compounds it contains represented by tannins and flavonoids, which inhibit the action of harmful bacteria in the gastrointestinal tract (Vijayanand and Hemapriya, 2011), so that the active compounds have their role in promoting and supporting the microbial balance within the gut and ultimately reflects on the general health of birds (Vasudha et al 2011). This result is in agreement with the findings of Safanah et al. (2012) that the aqueous and alcoholic extracts of nettle leaves have complete effectiveness in inhibiting bacteria, due to the effective compounds they contain (glycosides, tannins, flavonoids, phenols), and it is consistent with what was reported by Abouhosseini and others. (2016) on the efficacy of nettle root in increasing the numbers of Lactobacillus bacteria, and reducing the numbers of coliform bacteria in the gut of broilers compared with the control treatment. Cram-positive bacteria such as Coli are sensitive to plant extracts by interfering with the cell's cell membrane and changing its permeability by exchanging positive ions such as $\mathrm{k}+$ and $\mathrm{H}+$, which contribute to cell breakdown (Ultee et al. 2002) and phenolic compounds have an active role in this (Lambert et al., 2001). (Unlike the Cram-negative bacteria, which are equipped with an outer layer surrounding the cell membrane and act as a permeability barrier that prevents the hydrophobic compounds from reaching hydrophobic compounds, and since most plant extracts compounds are hydrophobic, the Gram-negative bacteria such as Lactobacillus exhibit greater resistance than the positive for the Cram stain) (Orndorff et al. It can be said that medicinal plants have a positive effect 
in multiple ways, such as stimulating the digestive process, as well as possessing anti-microbiological properties.

T1: a control. T2: adding an aqueous extract of nettle leaves at a level of $10 \mathrm{ml} /$ liter of water. T3: adding the aqueous extract of nettle leaves at a level of $15 \mathrm{ml} /$ liter of water. T4: add aqueous extract of nettle leaves at a level of $20 \mathrm{ml} /$ liter of water. * The different letters within one column indicate that there are significant differences between the groups at a probability level of 0.05 .

Table 6. Effect of nettle leaf water extract on the lleum of broilers (mean \pm standard error)

\begin{tabular}{cccc}
\hline Treatments & Total aerobic bacteria & Coliform bacteria & Lactobacilli \\
\hline T1 & $8.78 \pm 0.005 \mathrm{a}$ & $5.13 \pm 0.005 \mathrm{a}$ & $3.86 \pm 0.005 \mathrm{~d}$ \\
\hline $\mathrm{T} 2$ & $7.12 \pm 0.005 \mathrm{~b}$ & $4.23 \pm 0.008 \mathrm{~b}$ & $5.12 \pm 0.008 \mathrm{c}$ \\
\hline
\end{tabular}

Table 4. Effect of nettle leaf water extract on the Duodenum of broilers (mean \pm standard error)

\begin{tabular}{cccc}
\hline Treatments & Total aerobic bacteria & Coliform bacteria & Lactobacilli \\
\hline T1 & $10.76 \pm 0.005 \mathrm{a}$ & $6.42 \pm 0.005 \mathrm{a}$ & $2.13 \pm 0.005 \mathrm{~d}$ \\
\hline T2 & $9.84 \pm 0.005 \mathrm{~b}$ & $5.91 \pm 0.003 \mathrm{~b}$ & $3.06 \pm 0.014 \mathrm{c}$ \\
\hline T3 & $9.06 \pm 0.011 \mathrm{c}$ & $5.66 \pm 0.005 \mathrm{c}$ & $3.43 \pm 0.005 \mathrm{~b}$ \\
\hline T4 & $8.73 \pm 0.005 \mathrm{~d}$ & $5.22 \pm 0.005 \mathrm{~d}$ & $3.88 \pm 0.005 \mathrm{a}$ \\
\hline significance & $*$ & $*$ & $*$ \\
\hline
\end{tabular}


ISSN Onlin:2708-9347, ISSN Print: 2708-9339 Volume 9, Issue 1 (2020) PP 13-23

https://jam.utq.edu.iq/index.php/mai $\quad$ Doi: https://doi.org/10.54174/UTJagr.Vo9.N1/02

\begin{tabular}{cccc}
\hline T3 & $6.72 \pm 0.008 \mathrm{bc}$ & $3.91 \pm 0.003 \mathrm{c}$ & $5.41 \pm 0.005 \mathrm{~b}$ \\
\hline T4 & $5.35 \pm 1.000 \mathrm{c}$ & $3.71 \pm 0.012 \mathrm{~d}$ & $5.68 \pm 0.005 \mathrm{a}$ \\
\hline significance & $*$ & $*$ & $*$ \\
\hline
\end{tabular}

Table 5. Effect of nettle leaf water extract on the Jejunum of broilers (mean \pm standard error)

\begin{tabular}{cccc}
\hline Treatments & Total aerobic bacteria & Coliform bacteria & Lactobacilli \\
\hline T1 & $9.74 \pm 0.005 \mathrm{a}$ & $5.86 \pm 0.005 \mathrm{a}$ & $3.44 \pm 0.006 \mathrm{~d}$ \\
\hline T2 & $8.53 \pm 0.005 \mathrm{~b}$ & $4.62 \pm 0.005 \mathrm{~b}$ & $4.68 \pm 0.008 \mathrm{c}$ \\
\hline T3 & $8.28 \pm 0.008 \mathrm{c}$ & $4.36 \pm 0.005 \mathrm{c}$ & $4.94 \pm 0.008 \mathrm{~b}$ \\
\hline T4 & $8.02 \pm 0.008 \mathrm{~d}$ & $3.95 \pm 0.015 \mathrm{~d}$ & $5.34 \pm 0.011 \mathrm{a}$ \\
\hline significance & $*$ & $*$ & $*$
\end{tabular}

T1: a control. T2: adding an aqueous extract of nettle leaves at a level of $10 \mathrm{ml} /$ liter of water. T3: adding the aqueous extract of nettle leaves at a level of $15 \mathrm{ml} /$ liter of water. T4: add aqueous extract of nettle leaves at a level of $20 \mathrm{ml} /$ liter of water. * The different letters within one column indicate that there are significant differences between the groups at a probability level of 0.05 .

T1: a control. T2: adding an aqueous extract of nettle leaves at a level of $10 \mathrm{ml} /$ liter of water. T3: adding the aqueous extract of nettle leaves at a level of $15 \mathrm{ml} /$ liter of water. T4: add aqueous extract of nettle leaves at a level of $20 \mathrm{ml} /$ liter of water. ${ }^{*}$ The different letters within one column indicate that there are significant differences between the groups at a probability level of 0.05 .

\section{Conclusion}

The addition of nettle leaf (Urtica Dioica) aqueous extract to drinking water contributed to the improvement of the microbial characteristics of broilers by increasing the beneficial bacteria in the gastrointestinal tract and inhibiting harmful bacteria in comparison with the control treatment.

\section{References}

1- Abouhosseini T., M, Kh. Ghazvinian, M. Irani and R. Molaei. 2016. Effects of dietary supplementation of nettle root extract and pumpkin seed oil on production traits and intestinal microflora in broiler chickens. Bulgarian journal of veterinary medicine. No 2, 108-116. Issn 13111477; doi: 10.5547/bjvm.879.

2- AL- Rawi, A. and H. L.Chakravarty. 1988. Medical Plants of Iraq. Ministry of Agriculture and Irrigation. National Herbarium of Iraq. pp. 95-96. 
3- APHA (American Public Health Association). 1978. Standard Methods For The Examination Of Dairy Products.14th Ed. Marth. E.H. (Ed). American Public Health Association. USA, Washington .D.C.

4- Bhat, R.B. and G. Moskovitz. 2009. Herbal medicinal teas from South Africa. International Journal of Experimental Botany 78, 67-73.

5- Farhan, S. A. 2012. Study of Some Urtica dioica L. Leaves Components and Effect of Their Extracts on Growth of Pathogenic Bacteria and Identify of Some Flavonoids by HPLC. Al-Mustansiriyah Journal of Science, 23(3), 79-86.

6- Harrigan, W.F. and M.E. McCance .1976. Laboratory methods in food and Dairy microbiology. Academic press INC. (London) Ltd.

7- Hateem, M. W. 2017. Influence of spraying by suspended dry yeast bread and soaked licorice root and salsalic acid to resist fungus Sclerotinia sclerotiorum on eggplant. ANBAR JOURNAL OF AGRICULTURAL SCIENCES, 15(1), 237-243.

8- Hughes, Re., P. Ellery, T.Harry, V. Jenkis and E. Zones. 1980. The dietary potential of the common nettle. J. Sci. Food. Agr., 31: 1279-1286.

9- Kavalali, G.M. 2004. Urtica: Therapeutic and Nutritional Aspects of Stinging Nettles. Taylor and Francis Ltd, New York, pp. 15-90.

10- NRC .National Research Council . 1994 . Nutrient Requirements of Poultry. 9th ed. National Academic Press, Washington DC.

11- Roberts, M.2012. Healing Foods. Briza Publications, Queenswood, South Africa, p. 235.

12- Safanah A. F., M. Faraj , H. H. Al-Shemari , M. Abdul Kadir and N. Jassim. 2012. Study of Some Urtica dioica L. Leaves Components and Effect of Their Extracts on Growth of Pathogenic Bacteria and Identify of Some Flavonoids by HPLC. Al- Mustansiriya J. Sci. Vol. 23, No 3.

13- Speak, M. 1984. Compendium of Method for the Microbiological Examination for Food. 2nd Ed. Washington, D.C. USA.

14- SPSS. 2018. spss users guide. statistics version 23. Spss institute, Inc, Cary, NC.

15- Vasudha, P.A., R.C. Thangjam, C.H. Rituparna R.A. Bangar, L.O. Richard and B.A. Mamatha. 2011. Evaluation of the antimicrobial activity of Punicagranatum peels against the enteric pathogens: An invitro study. Asian J. Plant Sci. Res.(2):57-62.

16- Vijayanand S. and J. Hemapriya. 2011. Antibacterial Efficacy of Peels and Seed Extracts of In vitro PunicagranatumL against Selected Bacteria Strains. Int. J. Medicobio. Res. 1(4): 231-234.

17- Wenk, C. 2002. Herbs, botanicals and other related substances. WPSABremen. German.

18- Orndorff, B.W., Novak, C.L., Pierson, F.W., Caldwell, D.J., McElroy, A.P., 2005. Comparison of prophylactic or therapeutic dietary administration of capsaicin for reduction of Salmonella in broiler chickens. Avian Dis. 49, 527-533. 
19- Lambert, R.J.W., Skandamis, P.N., Coote, P., Nychas, G.J.E., 2001. A study of the minimum inhibitory concentration and mode of action of oregano essential oil, thymol and carvacrol. J. Appl. Microbiol. 91, 453-462.

20- Hernandez, M., R. Lopez , R.M. Abanas, V. Paris and A. Arias. 1994. Antimicrobial activity of Visnea mocanera Leaf extracts. J. Ethnopharmacology. 41 ; 115-119.

21- Ultee, A.; Bennik, H. J. \& Moezelaar, R. 2002. The phenolic hydroxyl group of carvacrol is essential for action against the food-borne pathogen, Bacillus cereus. Appl. and Env. Microbiol., 3: 15611568. 
ISSN Onlin:2708-9347, ISSN Print: 2708-9339 Volume 9, Issue 1 (2020) PP 13-23

https://jam.utq.edu.iq/index.php/mai $\quad$ Doi: https://doi.org/10.54174/UTJagr.Vo9.N1/02 